\title{
Genetic variation in perennial ryegrass for gas production during in vitro rumen fermentation
}

\author{
EN van Loo 1, D Reheul ${ }^{2}$, JW Cone ${ }^{3}$ \\ 'DLO-Centre for Plant Breeding and Reproduction Research (CPRO-DLO), PO Box 16, \\ 6700 AA Wageningen, The Netherlands ; 2 Rijksstation voor Plantenveredeling (RVP), Burg Van \\ Gansberghelaan 109, 9820 Merelbeke, Belgium; ${ }^{3} \mathrm{DLO}$-Institute for Animal Science and Health. Dep Ruminant \\ Nutrition, (ID-DLO), PO Box 160, 8200 AD Lelystad, The Netherlands
}

Genetic variation for fermentation kinetics was investigated in a set of clones, inbred families and populations of perennial ryegrass. The material was produced at two locations and consisted of a cut in late summer at two locations. Fermentation kinetics were studied using a time related gas production technique using buffered rumen fluid described by Cone et al (1994, Revista Portuguesa de Zootecnia, 1, 25-37). In most cases, three phases could be discriminated in the time course of gas production : an early, short phase (fermentation of water soluble carbohydrates), an intermediate, longer phase (fermentation of readily degradable cell walls) and a final phase of variable duration with fermentation of slowly degradable cell walls and perhaps lysis of microbial biomass. Consistent genetic variation in total gas production was found and location $x$ genotype interactions were not very important. The range (defined as the difference between max and min values within each group) in gas production within three groups of perennial ryegrass objects (cloned genotypes, inbred families and populations) was relatively larger just after the start of the rumen fluid incubations than at a later stage of fermentation (Table). Gas production techniques monitor carbohydrate fermentation mainly (both cell wall and soluble carbohydrates). Therefore, it can be concluded that large differences exist between genotypes in the amount of fast fermentable carbohydrates. In view of the fast ruminal degradation of proteins and the lack of synchronisation between protein and carbohydrate degradation, these results indicate that an increased efficiency of the use of ruminal nitrogen through plant breeding may be possible by selection for a faster degradation of cell walls. In vitro organic matter and cell wall matter degradability (after $48 \mathrm{~h}$ incubation) were predicted well using a multiple regression formula with cumulative gas production until 4,8 and 24 hours incubation, but only when differences in crude protein content were taken into account. Thus, gas production methods can be helpful in the search for faster and cheaper selection methods for genetic improvement of forage quality.
Cumulative gas production ( $\mathrm{ml}$ per g organic matter of sample)

\begin{tabular}{ccc}
\hline $4 \mathrm{~h}$ & $24 \mathrm{~h}$ & $48 \mathrm{~h}$ \\
69.6 & 197.2 & 237.7 \\
36.1 & 33.7 & 33.2 \\
73.2 & 198.1 & 239.5 \\
17.1 & 28.0 & 30.8 \\
71.0 & 197.1 & 240.1 \\
27.2 & 28.7 & 24.0 \\
4.4 & 5.7 & 8.8
\end{tabular}

